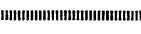 論 文

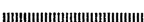 \\ $\mathrm{Ni}$ 基析出強化型超合金のクリープ破断寿命の 化学組成からの推定方法
}

\author{
藤岡 順三* ·宮下 卓也 ${ }^{*} \cdot$ 村瀬 宏一*2 \\ 西山 幸夫*2 ・松田 昭三*2
}

\section{A Predicting Method of the Creep Rupture Life of Nickel-Base Precipitation Hardened Superalloys from Chemical Composition}

\author{
Junzo FujIokA, Takuya Miyashita, Hirokazu Murase, \\ Yukio Nishiyama, and Shozo Matsuda
}

\section{Synopsis :}

The program for estimating the creep rupture life at $900^{\circ} \mathrm{C}$ from chemical composition has been developed on nickel-base precipitation hardened superalloys.

In this program, the steady state creep rate $\left(\dot{\varepsilon}_{S}\right)$ and the creep rupture life $\left(t_{\mathbf{r}}\right)$ have been estimated by Evans-Harrison's and Monkman-Grant's equations, respectively, which have been represented by the following equations.

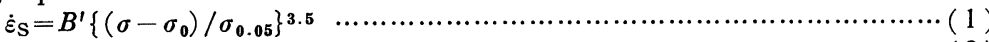

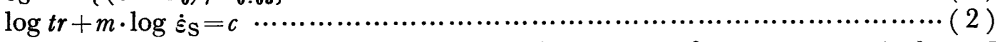

$\sigma, \sigma_{0}$ and $\sigma_{0.05}$ are applied stress, friction stress and $0.05 \%$ proof stress, respectively. $B^{\prime}$ is the constant for all alloys. $m$ and $c$ are constants for each alloy. $\sigma_{0}, \sigma_{0.05}, m$ and $c$ have been represented as a function of structural factors calculated from chemical composition. Relationship between $\sigma_{0}$ and structural factors has been led by the theoretical analysis based on the dislocation theory.

About $80 \%$ of the experimental creep rupture lives have fallen within a factor of two of the estimated lives at the various stress levels corresponding to the lives up to $10^{4} \mathrm{~h}$ as for twenty eight alloys. Especially, for cast alloys with higher $\gamma^{\prime}$ volume fraction, the creep strength has been estimated accurately by this program.

\section{1. 緒}

\section{言}

$\mathrm{Ni}$ 基析出強化型超合金は,オーステナイトマトリクス ( $\gamma$ 相) 中に微細整合析出した $\gamma^{\prime}$ 相 $\left[\mathrm{Ni}_{3}(\mathrm{Al}, \mathrm{Ti}, \mathrm{Nb}\right.$, Ta)］によつて強化された超耐熱材料であり，各種ガス タービン用高温部材として, 近年著しい発達を遂げてい る. これらの高温部材の設計要求值として, クリープ破 断強度, 熱疲労強度および耐食耐酸化性などが挙げられ る ${ }^{1)}$. 従来, 材料選定の際には, 上記の高温特性は, 新 規に 開発が 進められているデータのない合金に 関して は，析出強化作用を有する $\mathrm{Al}, \mathrm{Ti}$ ，固溶強化作用を有す る Co，Mo，W および耐食耐酸化性を付与する Cr な どの含有量による定性的推定手法によつて主に評価され てきた。しかし，化学組成からの電算機を利用した定量 的推定が可能になれば，多くの候補材料から非常に効率
良く材料が選定できる.

最近，合金開発の分野では，理論的な考察あるいは統 計的手法を用いて，合金設計が行われている2) 9).この 中で, 渡辺ら ${ }^{6 / 7)}$ は, 従来の組織要因 ${ }^{2) 8)}$ に関するデー タを分析し，電算機演算によつて合金元素含有量のすべ ての組み合わせの中からあらかじめ有効な合金組織を抽 出し, この限定された有効組成に関して, 実験的検討を 加党て最終的に実用上有用な合金組成を求めるといら手 法によつて，合金開発を行つている，さらに，原田ら ${ }^{9)}$ は，渡辺らの手法を踏ま兄て， $\gamma^{\prime} /\left(\gamma+\gamma^{\prime}\right)$ 界面を $\gamma^{\prime}$ 組成によつて数式化するなどの，新しい合金設計プロセ スを加味して, クリープ破断強度および耐硫化腐食性の 優れた TM-47，49 合金を開発している. しかしなが ら，これらの手法は，新合金の開発のための合金設計を 主目的としているので, 化学組成, 熱処理条件, クリー

昭和 55 年 10 月本会講演大会にて発表 昭和 55 年 10 月 13 日受付 (Received Oct. 13，1980)

* 川崎重工業 (株) 技術研究所 (Technical Institute, Kawasaki Heavy Industries, Ltd., 1-1 Kawasaki-cho Akashi 673)

*2 川崎重工業(株)技術研究所 工博 (Technical Institute, Kawasaki Heavy Industries, Ltd.) 
プ試験温度および付加応力などをインプットすれば破断 寿命がアウトプットされるといつた定量的な評価むでは 行つていないので, 材料評価プロセスに適用することは 難しい.

そこで，本研究においては，電算機を使用した合金設 計法に, 金属学的理論解析を加味した手法によつて, 化 学組成から $900^{\circ} \mathrm{C}$ における定常クリープ速度 ( クリープ破断寿命 $\left(t_{\mathrm{r}}\right)$ を算出する推定式の作成を試み た.

\section{2. クリープ破断寿命推定式作成の方針}

\section{1 破断寿命推定の基本的考え方}

化学組成から $\dot{\varepsilon}_{\mathrm{s}}, t_{\mathrm{r}}$ を推定する手順を Fig. 1 に示 す.まず，化学組成から組織要因をWOODYATT らの方 法10) と DECKER らの方法 ${ }^{11)}$ の折事的方法6) そ) によつて作 成したプログラムを用いて算出する. これらの組織要因 は図中に示すが，この中で， $\gamma^{\prime}$ 相中の $\mathrm{Ti}, \mathrm{Al}$ の原子 分率の比である $C_{\mathrm{Ti}} / C_{\mathrm{A} 1}$ は逆位相境界エネルギーに比 例する ${ }^{12)}$.

次に, このようにして得られた組織要因から $\dot{\varepsilon}_{\mathrm{S}}$ と $t_{\mathrm{r}}$ を算出するのであるが，媒介する式として Evans and HARRISON の式 $\left[(1)\right.$ 式 ${ }^{13) 14)}$ および Monkman and GRANT の式 [(2) 式 $]^{15)}$ を採用した.（1）式は， $\dot{\varepsilon}_{\mathrm{S}}$ の 応力依存性に従来用いられてきた SHERBY and BARRETT の式16)などとは異なり,純金属から分散強化型合金まで, friction stress $\left.\sigma_{0}\right)$ と $0.05 \%$ 耐力 $\left(\sigma_{0.05}\right)$ だけで整理 可能な式で, 定数 $B^{\prime}$ は材料に無関係に一定である.す なわち, 初期付加応力 $(\sigma)$ の代わりに $\sigma-\sigma_{0}$ を導入す ることによつて, 応力指数を 3.5 の一定值として取り扱 らことができ， $\sigma_{0.05}$ を導入することによつて，定常ク リープの活性化エネルギー, 拡散定数, 積層欠陥エネル ギーおよびャング率などを考慮する必要がなくなる.

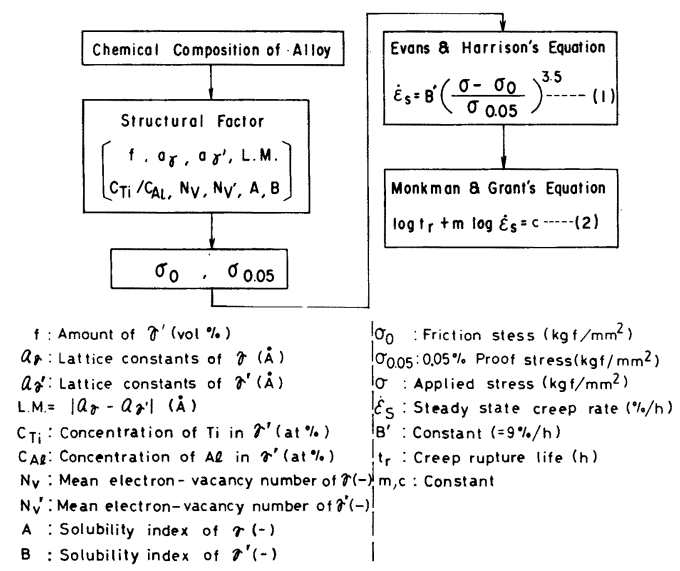

Fig. 1. Flow chart for estimating creep rupture life from chemical composition.

そこで, (1) 式中の $\sigma_{0}, \sigma_{0.05}$ および (2) 式中の定数 項 $m, c$ を組織要因によつて, ある温度で定量化できれ ば，Fig. 1 に示した手順により,化学組成からその温度 での $\dot{\varepsilon}_{\mathrm{S}}$ と $t_{\mathrm{r}}$ が求まる.

\section{2 推定式作成のための実験}

$2 \cdot 1$ 項で述べたように， $\dot{\varepsilon}_{\mathrm{S}}$ および $t_{\mathrm{r}}$ を求めるために は, $\sigma_{0}, \sigma_{0.05}, m$ および $c$ と組織要因との定量的な関係 を求める必要がある，そのために，まず最初に，9種の $\mathrm{Ni}$ 基析出強化型超合金について， $\sigma_{\mathbf{0}}, \sigma_{\mathbf{0 . 0 5}}, m$ および $c$ を実験によつて求めた. Table 1 に, これらの合金の 化学組成と熱処理条件を示す.ただし，この 9 種の合金 は，組織要因の中でクリープ強度に最も大きな影響を与 えると考えられる $f$ の計算值が，15～70 vol\% にわたる ように選んだ。実験はすべて $900^{\circ} \mathrm{C}$ で行つた. $\sigma_{0}$ の 測定は，WILLIAMS らの手法17) 21) で行つた. $\sigma_{0.05}$ は， ひずみ速度が $5 \times 10^{-5} \mathrm{~s}^{-1}$ の条件下での引張試験を行 つて求めた。 $m$ および $c$ を求めるために, クリープ扎よ

Table 1. Chemical composition and heat treatment. (wt \%)

\begin{tabular}{|c|c|c|c|c|c|c|c|c|c|c|c|c|c|c|c|}
\hline \multirow{2}{*}{ Alloy designation } & \multicolumn{12}{|c|}{ Element } & \multirow[b]{2}{*}{$\mathrm{Cu}$} & \multirow[b]{2}{*}{$\mathrm{Ni}$} & \multirow[b]{2}{*}{ Other } \\
\hline & C & $\mathrm{Si}$ & $\mathrm{Mn}$ & $\mathrm{Cr}$ & Co & Mo & $\mathrm{Al}$ & $\mathrm{Ti}$ & $\mathrm{Nb}$ & $\mathrm{B}$ & $\mathrm{Zr}$ & $\mathrm{Fe}$ & & & \\
\hline Inconel $700(\mathrm{~W})^{*}$ & 0.07 & 0.10 & 0.10 & 14.95 & 29.10 & 3.28 & 2.53 & 1.97 & - & - & - & 0.17 & 0.05 & Bal. & \\
\hline $\mathrm{MM} 007(\mathrm{C})$ & 0.09 & 0.35 & 0.01 & 8.16 & 9.71 & 5.82 & 5.91 & 0.62 & 0.004 & 0.016 & 0.040 & 00.05 & - & Bal. & $4.33 \mathrm{Ta}, 1.5 \mathrm{Hf}, 0.03 \mathrm{~W}$ \\
\hline Waspaloy (W) & 0.08 & 0.03 & 0.02 & 19.55 & 13.65 & 4.40 & 1.39 & 3.06 & - & 0.004 & $0 . .62$ & 0.32 & 0.01 & Bal. & $0.004 \mathrm{P}, 0.008 \mathrm{~S}$ \\
\hline Inconel $\times 750(W)$ & 0.03 & 0.20 & 0.35 & 15.31 & 0.84 & - & 0.97 & 2.27 & 1.01 & - & - & 7.43 & - & Bal. & - \\
\hline Udimet $500(W)$ & 0.07 & 0.10 & 0.10 & 18.70 & 19.20 & 4.00 & 3.01 & 2.99 & - & 0.004 & - & 0.16 & 0.10 & Bal. & - \\
\hline MM $004 \quad(C)$ & 0.03 & 0.06 & 0.01 & 12.33 & - & 3.89 & 5.65 & 0.42 & $\begin{array}{c}(\mathrm{Nb}+\mathrm{Ta}) \\
1.70\end{array}$ & 0.010 & 0.080 & 0.12 & 0.03 & Bal. & $\begin{array}{l}1.37 \mathrm{Hf} \\
0.005 \mathrm{~S}\end{array}$ \\
\hline Inconel $713 \mathrm{C}(\mathrm{G})$ & 0.13 & 0.15 & 0.03 & 13.10 & 0.05 & 4.42 & 6.19 & 0.93 & $\begin{array}{c}(\mathrm{Nb}+\mathrm{Ta} a) \\
2.46\end{array}$ & 0.011 & 0.090 & 0.10 & 0.03 & Bal. & $0.004 \mathrm{~S}$ \\
\hline René $100 \quad(\mathrm{C})$ & 0.17 & 0.10 & 0.10 & 9.20 & 14.30 & 2.90 & 5.47 & 4.82 & - & 0.014 & 0.040 & 00.12 & 0.10 & Bal. & $0.84 \mathrm{~V}, 0.001 \mathrm{~S}, 0.01 \mathrm{P}$ \\
\hline IN738LC $\quad(\mathrm{C})$ & 0.11 & 0.02 & 0.05 & 15.80 & 8.20 & 1.70 & 3.45 & 3.41 & 0.80 & 0.011 & 0.030 & 0.05 & 0.05 & Bal. & $0.01 \mathrm{P}, 1.9 \mathrm{Ta}, 2.6 \mathrm{~W}$ \\
\hline
\end{tabular}
* (W) : Wrought Alloy (C) : Cast Alloy

Heat Treatment

Inconel $700: 1180^{\circ} \mathrm{C} \times 2 \mathrm{~h}$, A.C. $+870^{\circ} \mathrm{C} \times 4 \mathrm{~h}$, A.C. Waspaloy : $1010^{\circ} \mathrm{C} \times 4 \mathrm{~h}$, W.Q. $+843^{\circ} \mathrm{C} \times 4 \mathrm{~h}$, A.C. $+760^{\circ} \mathrm{C} \times 16 \mathrm{~h}$, A.C.

Inconel $\times 750: 1150^{\circ} \mathrm{C} \times 2 \mathrm{~h}$, A.C. $+845^{\circ} \mathrm{C} \times 24 \mathrm{~h}$, A.C. $+705^{\circ} \mathrm{C} \times 20 \mathrm{~h}$, A.C. Udimet $500: 1088^{\circ} \mathrm{C} \times 4 \mathrm{~h}$, A.C. $+843^{\circ} \mathrm{C} \times 24 \mathrm{~h}, \mathrm{~A} . \mathrm{C}$.

$+760^{\circ} \mathrm{C} \times 16 \mathrm{~h}$, A.C. IN738LC: $1120^{\circ} \mathrm{C} \times 2 \mathrm{~h}$, A.C. $+845^{\circ} \mathrm{C} \times 24 \mathrm{~h}$, A.C. MM007, MM004, Inconel $713 \mathrm{C}$, René $100:$ As Cast 

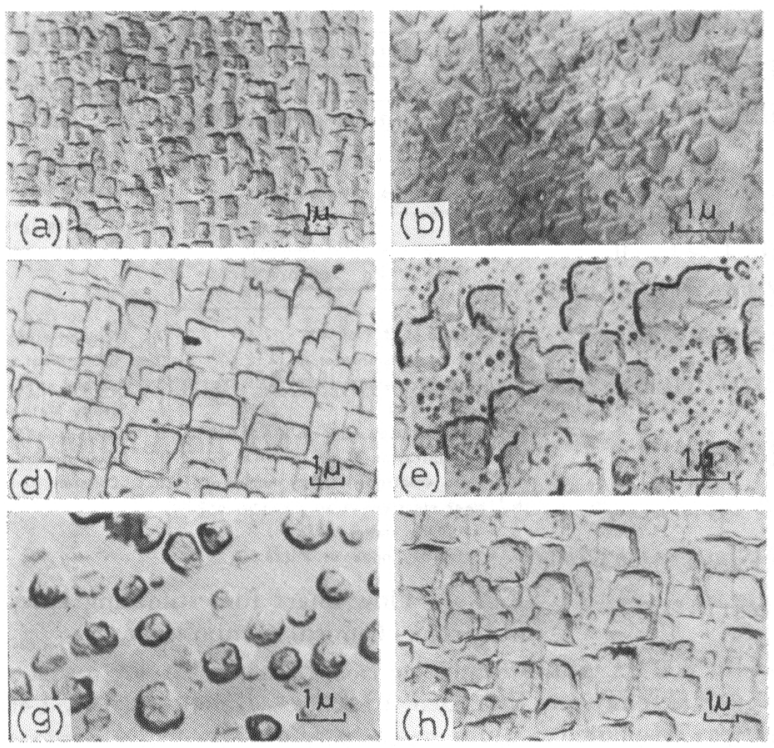
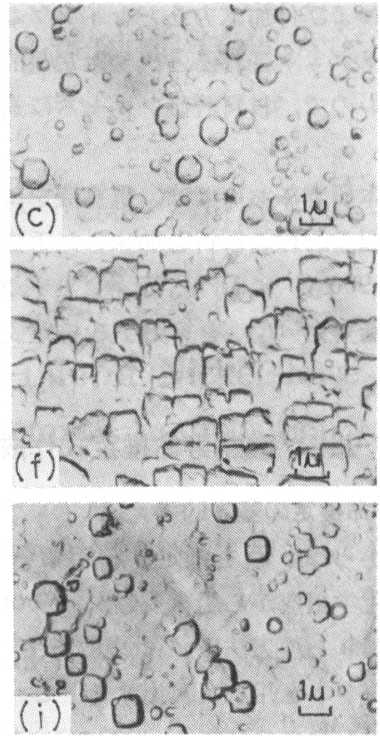

(a) Inconel 713C, (b) Inconel $\times 750$, (c) Inconel 700, (d) René 100, (e) Udimet 500,

(f) MM 007, (g) IN 738LC, (h) MM 004, (i) Waspaloy

Photo. 1. Result of TEM showing size, morphology and distribution of $\gamma^{\prime}$ particles.

びクリープ破断試験を, 各合金について 5 応力レベルで 行つた，そして，これらの実験から，定扎よび $t_{\mathrm{r}}$ を求 めた後に, ( 2 )式から $m$ および $c$ を算出した.

次に, この 9 種合金の試験前に扐ける $\gamma^{\prime}$ 粒子半径 （r）を透過型電子顕微鏡を用いて 2 段レプリカ法によ つて測定した. Photo. 1 に示すように, 個々の合金とも $\gamma^{\prime}$ 粒子の大きさ, 形態抏よび分布状態が異なつている. な拈, $\quad r$ の測定は, 微細な $\gamma^{\prime}$ 粒子を除外し, $\gamma^{\prime}$ 粒子

Table 2. Structural factors of 9 alloys for deducing equations.

\begin{tabular}{|c|c|c|c|c|c|c|c|c|c|c|}
\hline $\begin{array}{l}\text { Alloy } \\
\text { Designation }\end{array}$ & {$\left[\begin{array}{c}f \\
{[\text { vol\%] }}\end{array}\right]$} & $\left.\begin{array}{c}a \gamma \\
0 \\
{[\AA]}\end{array}\right]$ & 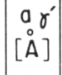 & $\begin{array}{l}\text { L.M. } \\
{[\AA]}\end{array}$ & $N_{V}$ & $\mathrm{~N}_{v^{\prime}}$ & A & B & $\frac{C_{T i}}{C_{A l}}$ & $\begin{array}{l}r \\
{[\mu]}\end{array}$ \\
\hline Inconel 700 & 30.0 & 3.5769 & 35805 & 0.0036 & 2.157 & 2.489 & 0.66 & 0.46 & 0.455 & 0.169 \\
\hline MM007 & 62.3 & 35846 & 35822 & 0.0024 & 4.082 & 2.364 & 0.79 & $\mid 0.41$ & 0.091 & 0407 \\
\hline Waspaloy & 21.6 & 35813 & 35904 & 00090 & 2.149 & 2353 & 0.80 & 0.87 & 1.536 & 0.218 \\
\hline Inconel $\times 750$ & 16.2 & 3.5628 & 36039 & 0.0411 & 1.695 & 2261 & 0.47 & 1.51 & 2.829 & 0.108 \\
\hline Udimet 500 & 34.1 & 3.5851 & 3.5830 & 0.0020 & D. 2338 & 2.412 & 0.86 & 0.57 & 0.646 & 0.123 \\
\hline MMO04 & 55.7 & 3.5795 & 55800 & 0,0005 & 52.060 & 2.332 & 0.82 & 0.38 & 0.057 & 0.496 \\
\hline Inconel $713 \mathrm{C}$ & 58.5 & 35806 & 635795 & 0.001 & 2.110 & 2.337 & 084 & 0.37 & 0.068 & 0.380 \\
\hline René 100 & 68.0 & 3.5821 & 35791 & 0003 & 2.263 & 2383 & 0.72 & 0.42 & 0.425 & 0.423 \\
\hline IN 738 LC & 48.9 & 35809 & & 0.0080 & 2.241 & 2331 & 0.84 & 078 & 0.609 & 0.311 \\
\hline
\end{tabular}

N. B. : Values of $r$ (radius of $\gamma^{\prime}$ particle) are experimental ones obtained from results of TEM showing size, morphology and distribution of $\gamma^{\prime}$ particle.
の形状が球と仮定して行つた. Table 2 に, $\quad r$ の測定結 果を他の組織要因と共に示す.

\section{$2 \cdot 3$ 性質要因と組織要因との定性的関係}

クリープ破断強度, 高温耐力拈よび組織安定性などと 組織要因との間の定性的な関係については, これまでに

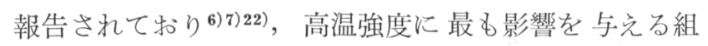
織要因は $\gamma^{\prime}$ 粒子の体積率 $(f)$ である. この他に, $\dot{\varepsilon}_{\mathrm{s}}$ は, $\gamma^{\prime}$ 相の積層欠陥エネルギー $\left(\mathrm{SFE}^{\prime}\right)$ と滑り面上の $\gamma^{\prime}$ 粒子の中心間距離 $\left(\Lambda^{\prime}\right)^{23)}$ が小さくなると減少し, $\sigma_{0.05}$ は, $\gamma^{\prime}$ 相の逆位相境界エネルギー $\left(\mathrm{APBE}^{\prime}\right)^{24)}$ 26) が大きくなると増加する10). このような定性的な関係を 念頭に置いて, $2 \cdot 2$ 項で述べた方法によつて実験的に求 めた $\sigma_{0}, \sigma_{0.05}$ および $m, c$ 之組織要因との定量的な関 係を, 解析によつて求めた. ただし, 後述するように, $\sigma_{0}$ の值は, 実験によつて求めた值を直接用いなかつた.

\section{3. 推定式の作成手順および作成結果}

\section{$3.1 \quad \sigma_{0}$ の組織要因による定量化}

$R$. LAGNEBORG と $B$. Bergman ${ }^{27)}$ は, 析出強化型合 金のクリープ変形中の back $\operatorname{stress}\left(\sigma_{\mathrm{P}}\right)$ の $\sigma$ 依存性を転 位論によつて説明している. この考方を Fig. 2 に示 す. ただし，本研究では $\sigma_{\mathrm{P}}=\sigma_{0}$ と仮定した. すなわ ち，析出強化型合金のクリープ変形においては， $\sigma$ の熱 成分である 有効応力がほぼ零に等しく, 非熱成分であ る内部応力 (internal stress) 28$) \sim 30$ 中 中転位構造成分 
$\left(\sigma_{\mathrm{e}}^{\prime}\right)$ がクリープ変形に寄与し, 粒子分散成分である $\sigma_{\mathrm{P}}$ が $\sigma_{0}$ として働くと考えた， $\sigma_{0}$ は，低 $\sigma$ 領域では（5) 式で示されるよらに $\sigma$ に対して傾き $a$ で直線的に増加 し，転位は上昇運動 (by-pass 機構) によつて $\gamma^{\prime}$ 粒子 を乗り越觉て進む。間 $\sigma$ 領域では $(6)$ 式で示されるよ らに $\sigma$ に対して一定で，転位は， $\gamma^{\prime}$ 粒子間距離が小さ い場合には主に cutting 機構で，大きい場合には主に Orowan 機構で $\gamma^{\prime}$ 粒子を通過する. 高 $\sigma$ 領域では (7) 式で示されるように $\sigma$ に対して傾さ $b$ で直線的に減少 し，このような高 $\sigma$ 下では $\gamma^{\prime}$ 粒子の $\gamma$ 相との整合歪み $(\mathrm{LM})$ が増加して, 転位の $\gamma^{\prime}$ 粒子に対する cutting 機 構が働かなくなると考えられる.

以上のような考え方をもとにして， $\sigma_{0}$ の組織要因に よる定量化を進めた. そのためには, Fig. 2 に示した 線図を各合金について求める必要があるが， $\sigma_{0}$ の測定 には非常に多くの労力を要するので, 次のような手順に よつて $\sigma_{0}$ を求めた。 まず，9種合金に関して，それぞ れ一つの $\sigma$ に対する $\sigma_{0}$ を実験によつて求めた. 次に,

(1) 式の変形式である下記の $(8)$ 式に, $\sigma, \sigma_{0.05}$ および $\dot{\varepsilon}_{\mathrm{s}}$ を代入し， $\sigma_{0}$ の逆計算值を求め， $\sigma_{0}$ の実測值と対比 した.この結果を Fig. 3 に示す.

$$
\sigma_{0}=\sigma-\sigma_{0.05} \cdot \sqrt[3]{\dot{\varepsilon}_{\mathrm{S}}} / B^{\prime}
$$

9 種合金とも， $\sigma_{0}$ の㬰測値と逆計算值とがかなり良 好な一致を示すので, 以下 $(8)$ 式から得られる $\sigma_{0}$ の逆 計算値の組織要因による定量化を進めた. なお, 求めら れた関係式は，それぞれの図中に示した。

Fig. 2 に示した（5)〜（7）式中の $\mathrm{a}, \mathrm{b}, \sigma_{\mathrm{e} 1}$ 㧊 よび $\sigma_{\mathrm{e} 2}$ を組織要因によつて定量化できれば，低 $\sigma$ から 高 $\sigma$ までに拈ける $\sigma_{0}$ が求まるが， $a$ の值は 9 種合金と も約 $\left.0.75^{27}\right) て ゙ あ り$, 高 $\sigma$ 側の $\sigma_{0}$ のデータ数が少ないた め, 以下 $\sigma_{\mathbf{c 1} 1}$ の組織要因による定量化を進めた.

$f$ が大きいほど, より高 $\sigma$ 側で by-pass 機構から cutting あるいは Orowan 機構に遷移すると考えて, $\sigma_{\mathrm{c} 1}$ を $f$ で整理した. その結果を Fig. 4 に示す. $\sigma_{\mathrm{c1}}$ と $f$ との関係式として $(9)$ 式が得られたが, $\pm 2.55 \mathrm{kgf} /$ $\mathrm{mm}^{2}$ の誤差範囲がある・

この誤差 $\left\{(0.537 f-3.21)-\sigma_{\mathrm{c} 1}\right\}$ を $\Lambda^{\prime}$ で整理した 結果を Fig. 5 に示す. MM 007 を除くと, その誤差と $\Lambda^{\prime}$ との間に, 熱処理材と As Cast 材とに区別して, そ れぞれ (10)，(11) 式に表される相関関係がある・ただ し， $\Lambda^{\prime}$ の值は下記の $(12)$ 式 ${ }^{23)}$ によつて $r$ と $f$ か算出 した.

$$
\Lambda^{\prime}=\sqrt[2]{2 \pi /(0.03 f)} \cdot r
$$

以上のようにして得られた $\sigma_{0}$ の組織要因による推定
式 $(5) \sim(12)$ 式を用いて計算した $\sigma_{0}-\sigma$ 線図を， $\sigma_{0}$ の逆計算值のプロットと対比させた結果を, Fig. 6 に 示す. Inconel X750 と Udimet 500 以外は, かなり良 好な一致を示す.

\section{$3.2 \sigma_{0.05}$ の組織要因による定量化}

$\sigma_{0.05}$ に最も大きな影響を与える $f^{31)}$ を用いて， $\sigma_{0.05}$ を整理した結果を Fig. 7 に示す. $\sigma_{0.05}$ と $f$ との関係 式として(13)式が得られたが， $\pm 5.25 \mathrm{~kg} f / \mathrm{mm}^{2}$ の䛊差 範用がある.

この誤差 $\left\{(0.484 f+12.3)-\sigma_{\mathbf{0 . 0 5}}\right\}$ を $C_{\mathrm{Ti}} / C_{\mathrm{A} 1}$ と $a_{r^{\prime}} / a_{\mathrm{Ni}_{3} \mathrm{Al}}$ とで整理することを試みたが $\left(a_{\mathrm{Ni}_{3} \mathrm{Al}}\right.$ は $\gamma^{\prime}$ 相の基本組成である $\mathrm{Ni}_{3} \mathrm{Al}$ の格子定数で $3.567 \AA$ ), $a_{r^{\prime}} / a_{\mathrm{Ni}_{3} \mathrm{Al}}$ ではこの 誤差と相関関係が得られなかつた

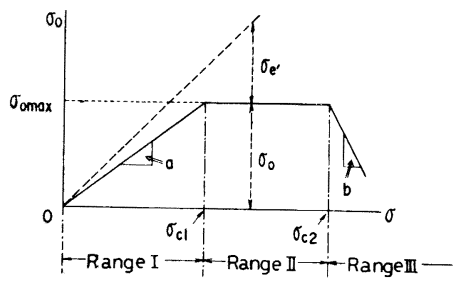

(3) $\sigma_{\mathrm{e}^{\prime}}:$ Component due to dislocation structure of internal stress
$\left[=\alpha \mathrm{Gb}^{\prime} \rho^{1 / 2} \ldots \ldots \ldots \ldots(4)\right]$

$\sigma_{0}$ : Component due to particle dispersion of internal stress Range I : Low-stress range where dislocations surmount particles by climbing motion. $\left\langle\sigma_{0}=a \sigma \cdots \cdots \cdots \cdots(5)\right\rangle$

Range II : Middle-stress range where particle passage occurs by Orowan or cutting mechanism. $\left\langle\sigma_{0}=\sigma_{0 \max }=a \sigma_{\mathrm{c} 1} \cdots(6)\right\rangle$

Range III : High-stress range where lattice mismatch between $\gamma$ and $\gamma^{\prime}$ increases and cutting mechanism doesn't occur. $<\sigma_{0}=b\left(\sigma-\sigma_{\mathrm{c} 2}\right)+a \sigma_{\mathrm{c} 1} \cdots \cdots \cdots \cdots(7)>$

Fig. 2. Variation of friction stress with applied stress.

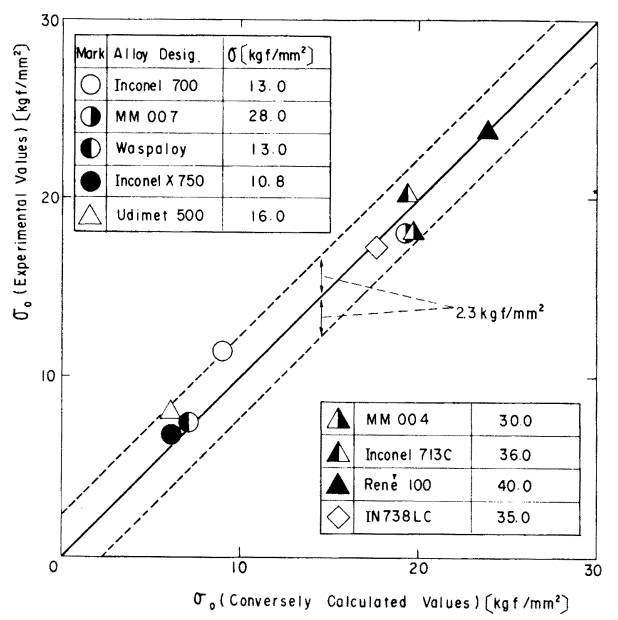

Fig. 3. Comparison of values calculated conversely by Evans and Harrison's Equation with experimental values for friction stress $\left(\sigma_{0}\right)$. 


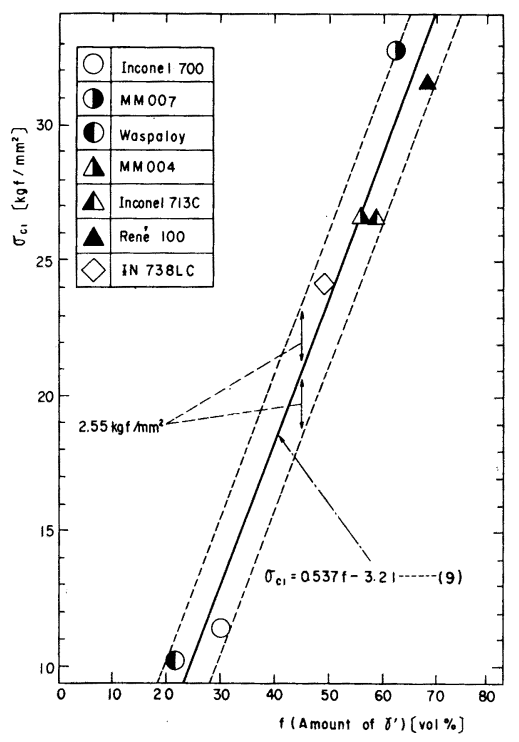

Fig. 4. Effect of amount of $\gamma^{\prime}$ on $\sigma_{\mathrm{c} 1}$.

のに対して， $C_{\mathrm{Ti}} / C_{\mathrm{A} 1}$ では相関関係が得られた，その結 果を Fig. 8 に示す. $f$ が小さいWaspaloy と Inconel X750を除くと, その䛊差と $C_{\mathrm{Ti}} / C_{\mathrm{Al}}$ との関係式とし て(14)式が得られた.

従つて, $f$ が $26 \mathrm{vol} \%$ 以下の合金には(13)式を, $f$ が $26 \mathrm{vol} \%$ より大きな合金には (14)式を適用して $\sigma_{0.05}$ を 算出したところ，この計算值と実測值とは，Fig. 9 に 示されるよらにかなり 良好な一致を呈し，誤差範囲は

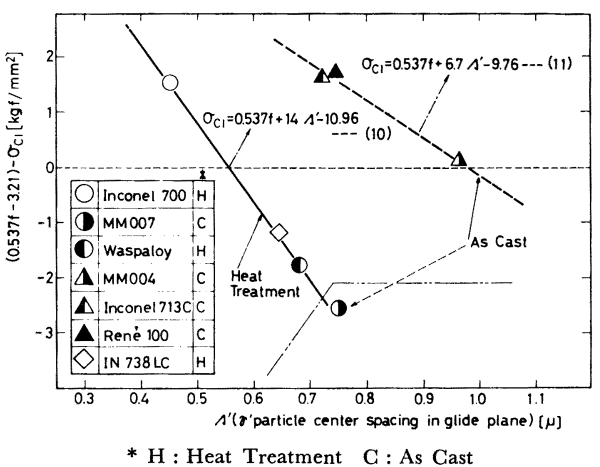

Fig. 5. Effect of $\gamma^{\prime}$ particle center spacing in glide plane on $\left.\left\{(0.537 f-3.21)-\sigma_{\mathrm{c} 1}\right)\right\}$.

$\pm 3.44 \mathrm{kgf} / \mathrm{mm}^{2}$ に減少した. ただし，(13)式と(14)式 の適用境界としての $f=26 \mathrm{vol} \%$ の值は，(14)式では整 理できなかつた合金中で $f$ が大きい方の Waspaloy，と (14)式で整理できた合金中で $f$ が最小の Inconel 700 と

の, $f$ の平均值を採つたものである.

\section{$3.3 m$ おおよび $\boldsymbol{c}$ の組䋨要因による定量化}

$m$ 抢よび $c$ と組織要因との相関性は現段階では明らか でないが，両者とも， $\mathrm{Ni}$ 基析出強化型超合金の高温特 性に最も大きな影響を与える組織要因である $f$ で整理し た.この結果を Fig. 10 に示す. $m$ は Waspaloy と Udimet 500 を除くと(15)式で表され，cは Inconel X750を除くと(16)式で表される.

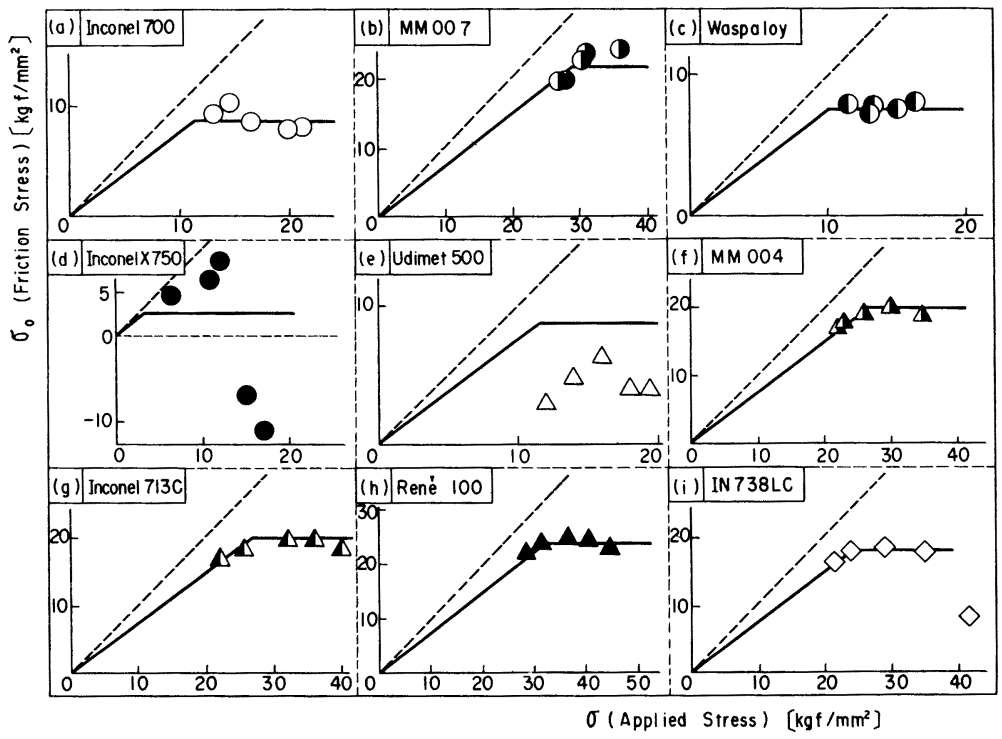

Fig. 6. Comparison of estimated values (-) with values calculated conversely

$(\bigcirc, \boldsymbol{\top}, \boldsymbol{\top}, \boldsymbol{\Theta}, \triangle, \boldsymbol{\Delta}, \Delta, \boldsymbol{\Delta}, \diamond)$ of fiction stress corresponding to applied stress. 


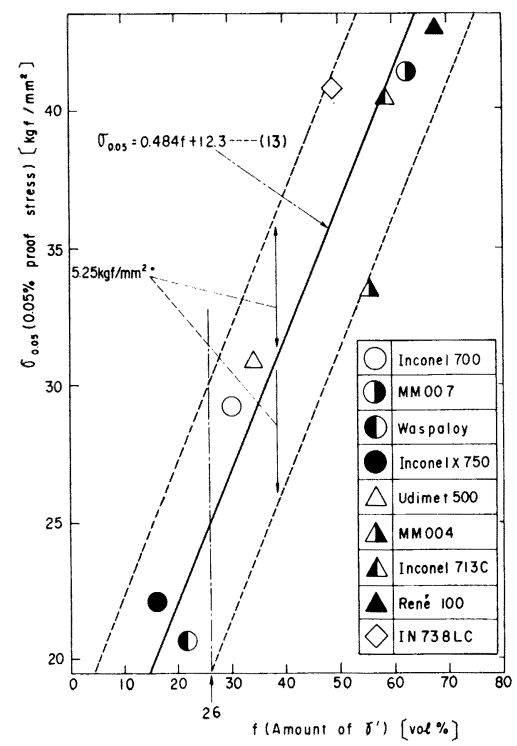

Fig. 7. Effect of amount of $\gamma^{\prime}$ on $0.05 \%$ proof stress.

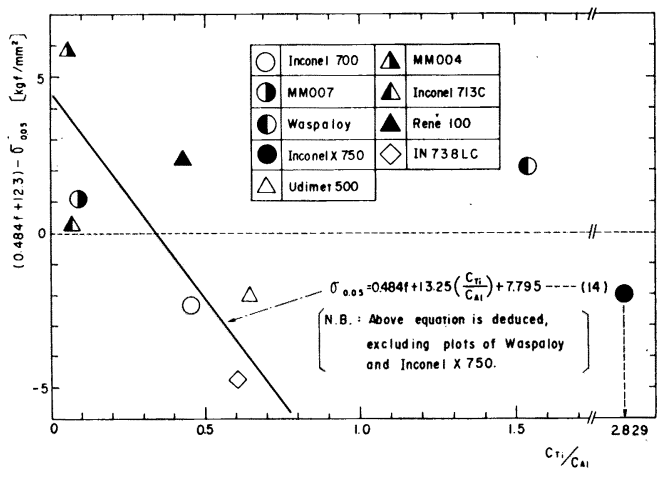

Fig. 8. Effect of $\left(C_{\mathrm{Ti}} / C_{\mathrm{A} 1}\right)$ on $\left\{(0.484 f+12.3)-\sigma_{0.05}\right\}$

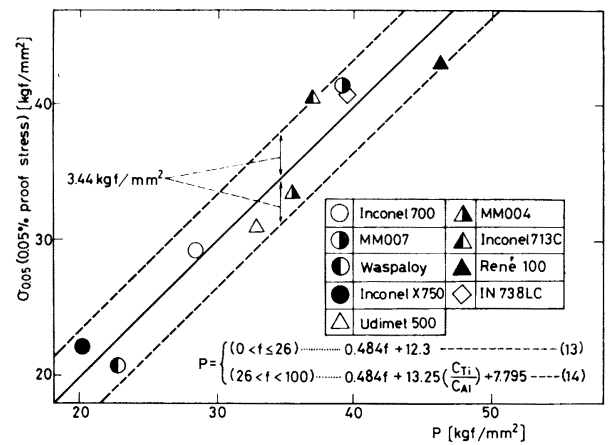

Fig. 9. Comparison of estimated values with experimental values of $0.05 \%$ proof stress.

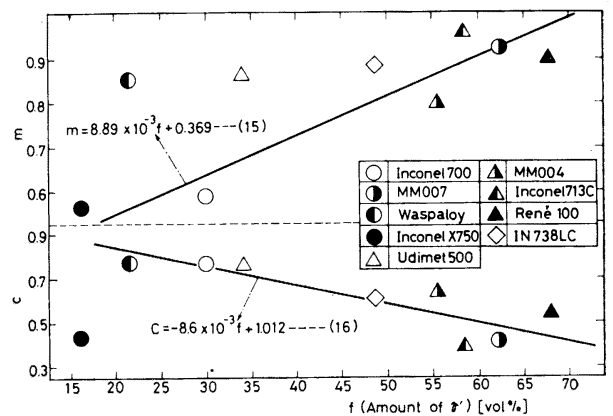

Fig. 10. Effect of amount of $\gamma^{\prime}$ on $m$ and $c$ in Monkman and Grant's equation.

Table 3. Equations for estimating creep rupture life.

\begin{tabular}{|c|c|}
\hline \multicolumn{2}{|r|}{$\dot{\varepsilon}_{\mathrm{s}}=B^{\prime}\left(\frac{\sigma-\sigma_{0}}{\sigma_{0.05}}\right)^{3 \cdot 5} \cdots \cdots \cdots \cdots \cdots(1) \quad \log t_{\mathrm{r}}+m \log \dot{\varepsilon}_{\mathrm{s}}=c \cdots \cdots \cdots(2)$} \\
\hline$\sigma_{0}$ & 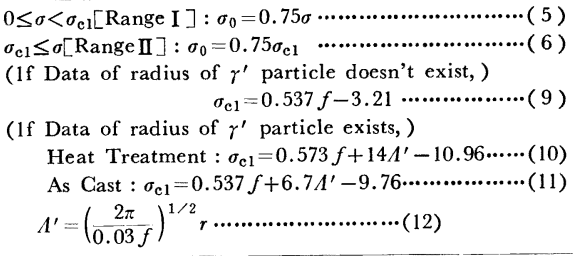 \\
\hline$\sigma_{0.05}$ & $\begin{array}{l}0<f \leq 26: \sigma_{3} .05=0.484 f+12.3 \cdots \cdots \cdots \cdots \cdots \cdots(13) \\
26<f<100: \sigma_{0.05}=0.484 f+13.25\left(\frac{C_{\mathrm{Ti}}}{C_{\mathrm{A} 1}}\right)+7.795 \cdots(14)\end{array}$ \\
\hline$m, c$ & $\begin{array}{l}m=8.89 \times 10^{-3} f+0.369 \\
c=-8.6 \times 10^{-3} f+1.012 \cdots \cdots \cdots \cdots \cdots \cdots(15)\end{array}$ \\
\hline
\end{tabular}

\section{4 推定式の作成結果}

$3 \cdot 1 \sim 3.3$ で行つた理論的解析により得られた $\sigma_{\mathbf{0}}$, $\sigma_{0.05}, m$ および $c$ の組織要因からの推定式を, Table 3 にまとめて示す.

\section{4. 推定式による $\dot{\boldsymbol{\varepsilon}}_{\mathrm{s}}$ と $\boldsymbol{t}_{\mathrm{r}}$ の試算結果}

Table 3 に示すように， $\sigma_{0} ， \sigma_{0.05}, m$ および $c$ を表中 の (5)〜（16）式を用いて計算し，これらの值を(1), (2) 式に代入すれば, $900^{\circ} \mathrm{C}$ に打ける任意の $\sigma$ に対する $\dot{\varepsilon}_{\mathrm{s}}$ と $t_{\mathrm{r}}$ とが推定できる.ただし， $\sigma_{\mathrm{c} 1}$ を(9)式から求 めるとrのデータがなくても化学組成だけから $\dot{\varepsilon}_{\mathrm{s}}$ と $t_{\mathrm{r}}$ を推定でさるが，透過型電子顕微鏡写真などによる $r$ の データがある場合には，(10)〜 (12) 式を活用することに よつて, $\dot{\varepsilon}_{\mathrm{s}}$ と $t_{\mathrm{r}}$ の推定精度の向上が期待される.この Table 3 から明らかなように, $\dot{\varepsilon}_{\mathrm{s}}$ と $t_{\mathrm{r}}$ とは, $f$ と $C_{\mathrm{Ti}} / C_{\mathrm{A} 1}$, そして $r$ のデータがある場合には $\Lambda^{\prime}$ に依存 し，中でも特に $f$ が大きな比重を占める.

まず最初に，本研究で推定式作成に必要なデータを採 つた 9 種合金に関して，化学組成と $r$ から $900^{\circ} \mathrm{C}$ に拉 
ける $\dot{\varepsilon}_{\mathrm{s}}$ と $t_{\mathrm{r}}$ を算出し，実測值と比較した。 その結果 をとれぞれ Fig. 11，12 に示す。 $\dot{\varepsilon}_{\mathrm{s}}$ に関しては，実測 值の約 $70 \%$ が計算值の $\times 1 / 2 \sim \times 2$ の範囲に入つてお り, 約 $80 \%$ が $\times 1 / 4 \sim \times 4$ の範囲に入つている. $t_{\mathrm{r}}$ に 関しては， $\dot{\varepsilon}_{\mathrm{s}}$ の推定精度より高く，実測值の約 $80 \%$ か 計算值の $\times 1 / 2 \sim \times 2$ の範囲に入つており, 約 $95 \%$ が $\times 1 / 4 \sim \times 4$ の範囲に入つている. $\dot{\varepsilon}_{\mathrm{s}}$ と $t_{\mathrm{r}}$ ともに計算 值と実測值との対応がよくないのは， Inconel X750 と Udimet 500 といつた比較的 $f$ の少ない合金で，動翼材 などに使用される $f$ が多くて角状の $\gamma^{\prime}$ 粒子が密に配列 している鋳造合金の $\dot{\varepsilon}_{\mathrm{s}}$ や $t_{\mathrm{r}}$ は，本推定式によつて, かなりの精度で算出が可能である.

次に，本推定式を上述の 9 種合金以外の合金に適用し て, $900^{\circ} \mathrm{C}$ に打ける $t_{\mathrm{r}}$ の計算值と実測值とを比較し た.この結果を Fig. 13 と示す.ただし，この場合，r のデータがないために，化学組成だけから推定した。 こ の場合も，実測値の約 $60 \%$ が計算值の $\times 1 / 2 \sim \times 2$ の 範囲に入つて招り，約 $90 \%$ が $\times 1 / 4 \sim \times 4$ の範囲に入 つている. No. 64 BC では, $10^{4}$ 時間程度まで $t_{\mathrm{r}}$ の計 算值と実測值が良好な一致を示しており，本推定式がか なり長時間の $t_{\mathrm{r}}$ まで高精度で算出できるものと期待さ れる.ささらに, Fig. 13 中にプロット (3)〜(5)で示した Inconel $713 \mathrm{C}$ の成分変化材の $\sigma=25 \mathrm{kgf} / \mathrm{mm}^{2}$ での $t_{\mathrm{r}}$ によるクリープ強度順位は，計算值と実測值とで同じで ある。

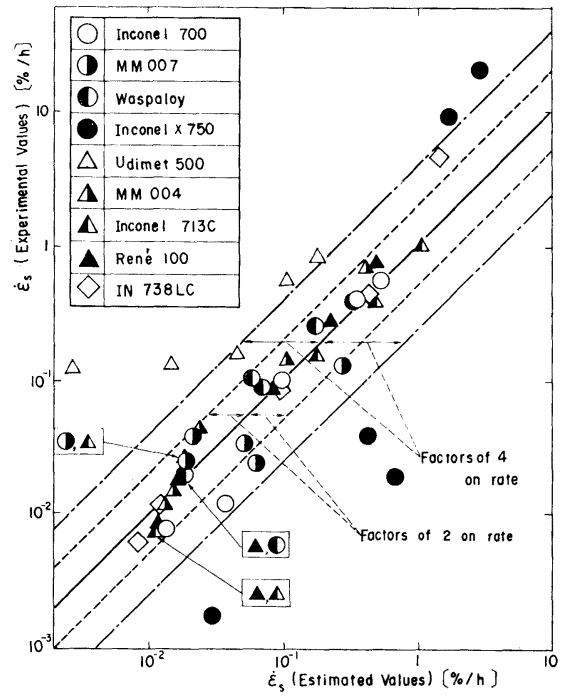

Fig. 11. Comparison of estimated values with experimental values of steady state creep rate.

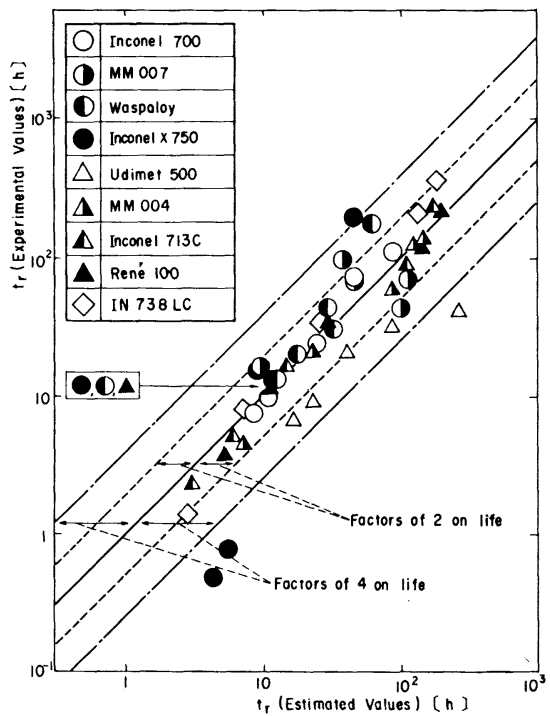

Fig. 12. Comparison of estimated values with experimental values of creep rupture life.

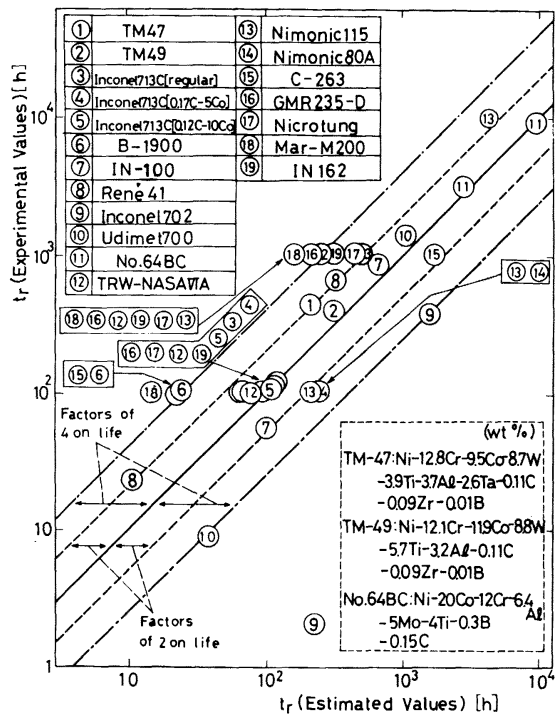

Fig. 13. Comparison of estimated values with experimental values of creep rupture life, on alloys except 9 ones used for deducing equations.

\section{5. 考}

\section{察}

$\sigma_{0}, \sigma_{0.05}, m$ および $c$ を組織要因によつて定量化して $900^{\circ} \mathrm{C}$ での $\dot{\varepsilon}_{\mathrm{s}}$ と $t_{\mathrm{r}}$ の推定式を作成し, 試算によつて その精度を確認した. 推定式に含まれる組織要因は， $f$ と $C_{\mathrm{Ti}} / C_{\mathrm{Al}}$ ，そして $r$ のデータがある場合にはさらに $\Lambda^{\prime}$ から構成され，特に $f$ の占める割合が大さい，そし て，作成された推定式はかなりの精度で $\dot{\varepsilon}_{\mathrm{s}}$ と $t_{\mathrm{r}}$ の予 
測を可能とすることから， $\mathrm{Ni}$ 基析出強化型超合金の $900^{\circ} \mathrm{C}$ 付近でのクリープ強度には $f$ が最も大きな影響を 与えることを示している. しかしながら， $\sigma_{0}, \sigma_{0.05}, m$ および $c$ と組織要因との定量的な相関を導く際に，相関 からはずれる例外の合金を除いた，従つて，相関からは ずれた原因を明らかにすることは，本推定法の適用可能 範囲拉よび今後の問題点を明確にするために重要なこと がらであると考えられるので，以下にこれらの点につい て考察を加える.

$\sigma_{0}-\sigma$ の関係における $\sigma_{\mathrm{c} 1}$ が Inconel X750 と Udimet 500 については求めることができず，その結果こ れらの合金の $\dot{\varepsilon}_{\mathrm{s}}$ と $t_{\mathrm{r}}$ は精度よく推定できなかつた. この理由は次のよらに考光られる. Fig. 2 に示した LAGNEBORG and BERGMAN の理論 ${ }^{27)}$ LM が非常に 小さい場合を仮定している. また， $f$ が $20 \mathrm{vol} \%$ 以下 の合金では常温でも $\gamma^{\prime}$ 粒子径が $280 \AA$ 以上で by-pass が起こるとされている11). 従つて， $f$ が $16.2 \mathrm{vol} \%$ で ある Inconel X750ではクリープ変形中にcutting が起 こらないので $\sigma_{0}$ が一定の Range II が表れず，さら に，LM が他の合金に比べて非常に大きいために上記 の理論が適用できない結果， $\sigma_{\mathrm{c} 1}$ が求められないと考え られる. 一方, Udimet 500 は, 他の合金と異なつて,

Photo. 1 に示すように約 $1.5 \mu$ の $\gamma^{\prime}$ 粒子の間に約 $0.1 \mu$ の小さな $\gamma^{\prime}$ 粒子が多量に析出している. このよ らに小さな $\gamma^{\prime}$ 粒子は cuttingされやすいので11)32)より 低応力側で Range I からIIへの遷移が起こり, Fig. 4 のように $\sigma_{\mathrm{c} 1}$ を $f$ だけで整理すると他の合金に比べて $\sigma_{\mathbf{c 1}}$ が非常に小さなものになると考兄られる. なお， $f$ の大きい鋳造合金の As Cast 状態では, 凝固後の冷却中 に非常に微細（約 $100 \AA$ ）な cooling $\gamma^{\prime}$ が析出してい ることが予想されるが31), この cooling $\gamma^{\prime}$ は $700^{\circ} \mathrm{C}$ 以上でマトリクスに固溶するので ${ }^{33)}, 900{ }^{\circ} \mathrm{C}$ でのクリー プ変形には寄与しない.

Fig. 5 に示すように, $\sigma_{\mathrm{cl}}-f$ の相関のズレ $\{(0.537 f-$ 3.21) $\left.-\sigma_{\mathrm{c} 1}\right\}$ を $\Lambda^{\prime}$ で整理した結果 As Cast 材と熱処 理材とに分かれて整理された. このことは，\{(0.537f$\left.3.21)-\sigma_{\mathrm{c} 1}\right\}$ には $\Lambda^{\prime}$ では表現しきれず，しかもAs Cast 材と熱処理材とで異なる因子が影響していること を示している. 前述したように cooling $\gamma^{\prime}$ は $900^{\circ} \mathrm{C}$ のクリープ変形中はマトリクスに固溶しているので,

Fig. 4 に示した $\sigma_{\mathrm{c1}}-f$ 関係の $f$ はクリープ変形に寄与 する $f$ で整理すべきであるが，ここでは cooling $\gamma^{\prime}$ も 含めた $f$ で整理されている. 一方, Fig. 5 の $\Lambda^{\prime}$ の中の $r$ の測定の際には cooling $\gamma^{\prime}$ を考虑していない.すな わち, Fig. 4 中の As Cast 材で cooling $\gamma^{\prime}$ も含めた $f て ゙ \sigma_{\mathrm{c} 1}$ を整理したことが，Fig. 5 において熱処理材 と As Cast 材に分かれた理由の1つになつていると考 えられる.

次に, $\sigma_{0.05}$ と組織要因との相関について考察を行う. 高温耐力と組織要因との関係については多くの研究が行 われているが， $\gamma^{\prime}$ 粒子が cutting される条件下での高 温耐力は $f$ c $r / \gamma^{\prime}$ 境界の性質, $\gamma^{\prime}$ 粒子自身の性質に 依存する。この中で, $r / \gamma^{\prime}$ 境界の性質を表す組織要因 は LM とこれによつてもたらされる整合歪みで, $\gamma^{\prime}$ 粒 子自身の性質を表す組織要因は APBE' と $r^{\prime}$ 粒子の固 溶強化因子であり，この固溶強化因子は $a_{r^{\prime}}$ （あるいは $\left.a_{r^{\prime}} / a_{\mathrm{Ni}_{3} \mathrm{Al}}\right)$ で代表させることができる6). BEARDMORE 等31)が $f$ 20〜 100 vol\% に変化させた Ni-Cr-Al 合 金の耐力の温度依存性を調べた結果によると, $850^{\circ} \mathrm{C}$ ま での耐力の大小は $f$ だけでは説明できないが，850。 $\mathrm{C}$ 以 上ではほぼ $f$ と耐力とは比例関係にある.そして，この 現象は耐力が最大值を示すピーク温度を過ぎてからの APBE' の減少による耐力の低下によつてもたらされて いる31). また, LEVERANT ら ${ }^{34)}$ は, Mar-M 200 の耐力 が, $760^{\circ} \mathrm{C}$ までは $\mathrm{APBE}^{\prime} に$ ，それ以上では $\mathrm{APBE}^{\prime}$ と $\gamma^{\prime}$ 粒子自身の流動応力に支配されることを示している. 一方, 整合歪の重要性については支持する意見 ${ }^{35)}$ と批判 的な意見があり 12)36) 38), 重要な場合も低温に限られる ようである ${ }^{33) 35)}$. 以上の理由から, 本研究においては, まず最初に $\sigma_{0.05}$ に最も影響を与える $f$ で整理し, $\sigma_{0.05}$ と $f$ との相関のズレ $\left\{(0.484 f+12.3)-\sigma_{0.05}\right\}$ APBE' と密接な関係にある $C_{\mathrm{Ti}} / C_{\mathrm{Al}}$ と $a_{r^{\prime}} / a_{\mathrm{Ni}_{3} \mathrm{Al}}{ }^{12) 39)}$ で整 理することを試みた. $\left\{(0.484 f+12.3)-\sigma_{\mathbf{0 . 0 5}}\right\}$ と $C_{\mathrm{Ti}} /$ $C_{\mathrm{A} 1}$ の相関は, Fig. 8 に示すように, $f$ が $26 \mathrm{vol} \%$ 以 上の合金について得られたが， $f$ が $26 \mathrm{vol} \%$ 以下の合 金に対して $C_{\mathrm{Ti}} / C_{\mathrm{A} 1}$ で整理できないのは，前述したよ らに, cutting が起こらないために $\gamma^{\prime}$ 粒子自身の性質 に耐力が依存しないためであると考光られる. 一方, $a_{r^{\prime}} / a_{\mathrm{Ni}_{3} \mathrm{Al}}$ で整理できなかつたのは次のような理由によ るものと考光られる. DECKER ${ }^{11)}$ の解析によると, $400^{\circ} \mathrm{C}$ あたりまでの $\gamma^{\prime}$ 粒子自身の強化は $\mathrm{Cr}, \mathrm{Ti}, \mathrm{Mo}(\mathrm{W})$ に

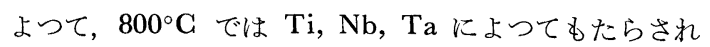
る.しかしながら， $\gamma^{\prime}$ 粒子中の $\mathrm{Al}$ を $\mathrm{Ti}, \mathrm{Nb}, \mathrm{Ta}$ で

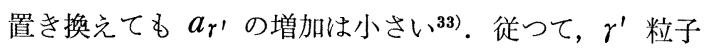
の $900^{\circ} \mathrm{G}$ 付近での固溶強化を表すためには， $a_{r^{\prime}}$ 以外 の因子を用いなければならないと考劣られる。ただし， $C_{\mathrm{Ti}} / C_{\mathrm{A} 1}$ は, $\mathrm{Mo}(\mathrm{W})$ の $\gamma^{\prime}$ 粒子中への固溶量が増すこ とに伴う $C_{\mathrm{A} 1}$ の低下によつても増加するため, $\mathrm{Mo}(\mathrm{W})$ 量も $\gamma^{\prime}$ 粒子の固溶強化に関接的に影響している可能性 も考えられる. 


\section{6. 結}

言

本研究では, $\mathrm{Ni}$ 基析出強化型超合金のクリープおよ びクリープ破断強度を, 主として化学組成から算出する ために，電算機を利用した組織要因の算出と金属学的理 論解析による推定式の作成を展開した.

そして, この推定式に基づて, 本研究で推定式作成 に必要なデータを採つた 9 種合金に関して，化学組成と $r$ から $900^{\circ} \mathrm{C}$ における $\dot{\varepsilon}_{\mathrm{s}}$ と $t_{\mathrm{r}}$ を算出した結果と実 測値を比較したところ，両者の間にかなりよい一致が得 られた。

次に, 上述の 9 種合金以外の合金に関して, 化学組成 だけから $900^{\circ} \mathrm{C}$ における $t_{\mathrm{r}}$ を算出した結果と実測值 を比較しても，両者の間にかなりよい一致が得られ， No. 64BG では, $10^{4}$ 時間程度をで良好な一致を示し た. さらに, Inconel $713 \mathrm{G}$ の成分変化材の等付加応力 での $t_{\mathrm{r}}$ によるクリープ強度順位が，計算值と実測值と で同じであり, Inconel 713G レベルの合金に対して，こ の推定式の精度が特によいと考学られる.

従つて，本推定式は，rのデータがない場合でも，動 翼材などに使用される $f$ が多くて角状の $\gamma^{\prime}$ 粒子が密に 配列している鋳造合金の，900 $\mathrm{G}$ における長時間クリ一 プの $\dot{\varepsilon}_{\mathrm{S}}$ や $t_{\mathrm{r}}$ を精度よく算出可能だと，期待できる.

\section{記 号}

$\dot{\varepsilon}_{\mathrm{s}}:$ 定常クリープ速度 $[\% / \mathrm{h}]$

$t_{\mathrm{r}}:$ クリープ破断寿命 [h]

$f: \gamma^{\prime}$ 粒子の体積率 [vol\%]

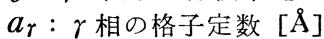

$a_{\gamma^{\prime}}: \gamma^{\prime}$ 相の格子定数 [ $[\AA]$

$\mathrm{LM}: a_{\tau}$ と $a_{\gamma^{\prime}}$ の差の絶対值 (Lattice Mismatch) $[\AA]$

$C_{\mathrm{Ti}}: \gamma^{\prime}$ 相中の $\mathrm{Ti}$ の原子分率 [at $\%$ ]

$C_{\mathrm{A} 1}: \gamma^{\prime}$ 相中の $\mathrm{Al}$ の原子分率 [at \% ]

$N_{\mathrm{v}}: \gamma$ 相の平均電子空孔数 (Average Electronvacancy Number)

$N_{\mathrm{v}}^{\prime}: \gamma^{\prime}$ 相の平均電子空孔数

$A: \gamma$ 相の固溶指数

$B: \gamma^{\prime}$ 相の固溶指数

$\sigma_{0}$ : 内部応力の粒子分散成分 (Friction Stress) $\left[\mathrm{kgf} / \mathrm{mm}^{2}\right]$

$\sigma_{0.05}: 0.05 \%$ 耐力 $\left[\mathrm{kgf} / \mathrm{mm}^{2}\right]$

$B^{\prime}$ : 定数 $[=9 \% / \mathrm{h}]$

$\sigma:$ 初期付加応力 $\left[\mathrm{kgf} / \mathrm{mm}^{2}\right]$

$m, c:$ 定数

$r: \gamma^{\prime}$ 粒子半径 $[\mu]$

$\mathrm{SFE}^{\prime}: \gamma^{\prime}$ 相の積層欠陥エネルギー $\left[\mathrm{erg} / \mathrm{cm}^{2}\right]$

$\Lambda^{\prime}$ : すべり面上の $\gamma^{\prime}$ 粒子の中心間距離 $[\mu]$

$\mathrm{APBE}^{\prime}: \gamma^{\prime}$ 相の逆位相境界エネルギー $\left[\mathrm{erg} / \mathrm{cm}^{2}\right]$ $\sigma_{\mathrm{P}}:$ Back Stress $\left[\mathrm{kgf} / \mathrm{mm}^{2}\right]$ $\sigma_{\mathrm{e}}^{\prime}$ : 内部応力の転位構造成分 $\left[\mathrm{kgf} / \mathrm{mm}^{2}\right]$

$\alpha$ : 転位障害物の強度を示す無次元定数 $[=0.6 \sim 1.2]$

$G$ : 剪断弾性係数 $\left[\mathrm{kgf} / \mathrm{mm}^{2}\right]$

$b^{\prime}$ : Burgers Vector の大きさ $[\mathrm{mm}]$

$\rho:$ 転位密度 $\left[\mathrm{mm} / \mathrm{mm}^{3}\right]$

$a:$ 定数 $[\fallingdotseq 0.75]$

$b$ : 定数

$\sigma_{\text {max }}$ : Friction Stress の付加応力第 2 領域における 值 $\left[\mathrm{kgf} / \mathrm{mm}^{2}\right]$

$\sigma_{\mathrm{c1} 1}$ : 付加応力第 1 領域から第 2 領域に遷移する臨界 応力 $\left[\mathrm{kgf} / \mathrm{mm}^{2}\right]$

$\sigma_{\mathrm{c2}}$ : 付加応力第 2 領域から 第 3 領域に遷移する臨界 応力 $\left[\mathrm{kgf} / \mathrm{mm}^{2}\right]$

$a_{\mathrm{Ni}_{3} \mathrm{Al}}: \gamma^{\prime}$ 相の基本組成である $\mathrm{Ni}_{3} \mathrm{Al}$ の格子定数 $[=3.567 \AA]$

\section{交献}

1 ）湯川夏夫：日本金属学会会報，11（1972）10, p. 707

2 ）湯川夏夫：学振 123 委研究報告, 18 (1977) 3 , p. 291

3 ) $H . E$. Collins, $R . J$. Quigg, and $R . L$. DreshField: Trans. ASM, 61 (1968), p. 711

4 ) 大村泰三：学振 123 委研究報告, 14 (1973) 3, p. 165

5 ) 大村泰三，佐平健彰，迫八岡晃彦，米沢 登：鉄 々鋼，62(1976) 1, p. 1363

6 ）渡辺力蔵，九重常男：鉄と鋼，61（1975）, p. 2274

7 ) 渡辺力蔵, 九重常男：学振 123 委研究報告, 15 (1974) 1, p. 17

8 ）金子秀夫：日本金属学会会報，8 (1969) 8, p.532

9 ) 原田広史, 山崎道夫：鉄と鋼, 65 (1979), p. 1059

10) L. R. Woodyatt, $C . T$. Sims, and $H . J$. Beattie: Trans. Met. Soc. AIME, 236 (1966), p. 519

11) R. F. Decker: 'Strengthening Mechanisms in Nickel-Base Superalloys', Steel Strengthening Mechanisms Symposium, Zurich, (May. 1969)

12) L. K. Sing hal: Script. Met., 5 (1971), p. 959

13) $W . J$. Evans and $G . F$. Harrison: Metal Sci. J., 10 (1976) 9, p. 307

14) $W . J$. Evans and $G . F$. Harrison: Metal Sci. J., 13 (1979) 11, p. 641

15) $F$. C. Monkman and $N . J$. Grant: Proc. ASTM, 56 (1956), p. 593

16) C. R. Barrett and $O . D$. Sherby: Trans. Met. Soc. AIME, 233 (1965), p. 1116

17) $K . R$. Williams and $B$. Wilshire: Metal Sci. J., 7 (1973), p. 176

18) K. R. Williams: Metal Sci. J., 10 (1976) 9 , p. 332

19) J. C. Gibeling and $W$. D. Nix: Metal Sci. J., 11 (1977) 10, p. 453

20) $H$. Burt, $J$. P. Dennison, and $B$. Wilshire: Metal Sci. J., 13 (1979) 5, p. 295

21) $W . J$. Evans and $G . F$. Harrison: Metal Sci. J., 13 (1979) 6, p. 346 
22) R. F. Decker: Met. Trans., 4 (1973) 11, p. 2495

23) A. Melander and $P$. A. Persson: Metal Sci. J., 12 (1978) 9, p. 391

24) P. A. Flinn: Trans. Met. Soc. AIME, 218 (1960) 2, p. 145

25) $B . H$. Kear, $J . M$. Oblak, and $A . F$. GiaMEI: Met. Trans., 1 (1970) 9, p. 2477

26）辛島誠一, 及川洪, 渡辺忠雄: 日本金属学会会 報，5 (1966) 8，p. 517

27) $R$. Lagneborg and $B$. Bergman: Metal Sci. J., 10 (1976) 1, p. 20

28）長谷川正，及川 洪：日本金属学会会報，11 (1972) 3, p. 192

29) L. J. Cuddy: Met. Trans., 1 (1970) 2, p. 395

30) H. Conrad: J. Metals, 16 (1964) 7, p. 582

31) P. Beardmore, R. G. Davies, and $T . L$. Johnston: Trans. Met. Soc. AIME, 245 (1969), p. 1537

32) W. I. Mitchell: Z. Metallk., 57 (1966), p. 586

33) R. G. Davies and T. L. Johnston: "The
Metallurgical Design of A Superalloy”, 3rd Bolten Landing Conf. on Ordered Alloy, ed. by $B$. $H$. Kear et al., Claitors Publishing Division, Baton Rounge, La., (1970), p. 447

34) G. R. Leverant, $M$. Gell, and $S . W$. Horkins: "The Influence of the $\gamma^{\prime}$ Precipitate on the Elevated Temperature Strength and Drformation Characteristics of A NickelBase Alloy", 2 nd Int. Conf. Strength of Metals and Alloys, ASM (1970), p. 1141

35) J. R. Mihalism and $R . F$. Decker: Trans. Met. Soc. AIME, 218 (1960), p. 507

36) $S$. $M$. Copy and $B$. H. Kear: Trans. Met. Soc. AIME, 239 (1967), p. 984

37) V. A. Phillips: Phil. Mag., 16 (1967), p. 103

38) V. A. Phillips: Script. Met., 2 (1968), p. 147

39) $R . H$. H Precipitates", 3 rd Bolten Landing Conf. on Ordered Alloy, ed. by, B. H. KeAR et al., Claitors Publishing Division, Baton Rouge, La., p. 365 